\title{
Erzurum İli Narman İlçesi Sığır Yetiştiricilerinin Sığır Besleme Tercihleri
}

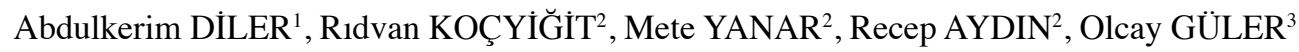

ÖZET: Bu araştırma, sığır yetiştiricilerinin sı̆̆ır besleme ve yemleme alışkanlıklarını ortaya koymak amacıyla Erzurum İli Narman İlçesi'nde yapılmıştır. Bu amaçla Narman ilçe ve köylerinde 208 işletme sahibiyle anket çalışması yapılarak veriler elde edilmiştir. Araştırmada elde edilen bulgulara göre yetiştiricilerin \% 80.8'inin yem bitkisi üretimi yaptığı saptanmıştır. Bu işletmelerde çoğunlukla yonca (\% 61.5) ve arpa (\% 60.1) üretimi yapıldığı belirlenmiş̧ir. Ancak önemli kaba yem kaynağı olan silajlık mısır üretimi düşük düzeyde $(\% 7.7)$ yapılmaktadır. Mera kullanım oranı \% 96.2 olup genellikle Mayıs (\% 47.5) veya Haziran (\% 37) aylarında meraya çıkış gerçekleşmektedir. Meradan yararlanma süreleri ise 3 ay (\% 31) veya 4 ay (\% 68) olarak belirlenmiştir. İşletmelerin \% 41'inin yaylaya çıkma imkânı olduğu, Mayıs-Haziran aylarında yaylalara çıktıkları ve çoğunlukla 4 ay (\% 43) kaldıkları tespit edilmiştir. İşletmelerde kullanılan kaba yem kaynaklarında buğday-arpa samanı (\% 27) ilk sırayı alır iken bunu kuru yonca (\% 21) ve kuru çayır otu (\%16) takip etmektedir. Silaj ise düşük düzeyde (\% 7) kullanılmaktadır. İşletmelerde kesif yem olarak genellikle arpa kırması (\% 34), besi yemi (\% 23) ve süt yemi (\% 22) kullanılmaktadır. İlçede meranın ıllah edilerek, aktif kullanımı, yem bitkileri üretimi ve özellikle mısır silajı üretiminin arttırılması gerekli görülmektedir. Ayrıca tarımsal yayım hizmetlerinin kırsal alanlarda yoğunlaştırılması yetiştiriciler için faydalı olacaktır.

Anahtar kelimeler: Besleme alışkanlığı, Erzurum, Narman, sığır, yem bitkileri

\section{Cattle Feeding Habits of Cattle Enterprises in Narman County of Erzurum Province}

\begin{abstract}
This study was carried out in order to reveal cattle nutrition and feeding habits of cattle enterprises in Narman country of Erzurum province. For this purpose, some data were obtained by conducting face to face survey study with 208 producers in Narman and it's villages. According to the findings obtained in the survey, it was determined that $80.8 \%$ of the enterprises produced forage crops. In these enterprises, alfalfa $(61.5 \%)$ and barley $(60.1 \%)$ were mainly planted, but production of corn silage which is a major roughage feed was at low level (\%7.7). Pasture utilization ratio was $96.2 \%$ and cattle herds generally moved into the pasture in May (47.5\%) or June (37\%). Time interval that herds are grazed in pasture as determined as 3 months (31\%) or 4 months (68\%). It was also found out that $41 \%$ of the cattle breeder had a chance to move to the upland, they mostly went there in May or June and stayed in the upland for 4 months (43\%). While wheat and barley straws (27\%) take the first order as roughage in the enterprises, they were followed by alfaalfa hay $(21 \%)$ and grass hay $(16 \%)$. Silage $(7 \%)$ was used at a low level. In enterprises crushed barley (34\%), feed for fattening (23\%) and feed for milk production (22\%) were mostly used as concentrated feed. Excessive pasture usage in the country makes it necessary to improve the quality of pasture and to increase the production of forage crops, especially corn silage. Also concentration of agricultural extension services in rural areas will be beneficial for ranchers.
\end{abstract}

Key words: Cattle, Erzurum, Narman, feeding habits, forage crops,

\footnotetext{
Abdulkerim DILLER (0000-0001-7958-6179), Atatürk Üniversitesi , Erzurum Meslek Yüksekokulu, Bitkisel ve Hayvansal Üretim Bölümü, Erzurum, Turkey

2 Rıdvan KOÇYİ̆̆iT (0000-0003-4584-9676), Mete YANAR (0000-0002-2280-0899), Recep AYDIN (0000-0001-9319-9319), Atatürk Üniversitesi, Ziraat Fakültesi, Zootekni Bölümü, Erzurum, Turkey

Olcay GÜLER (0000-0001-8849-8680), Atatürk Üniversitesi , Hınıs Meslek Yüksekokulu , Laboratuar Veteriner Sağlık Bölümü, Erzurum, Turkey

Sorumlu yazar/Corresponding Author: Recep AYDIN, raydin@atauni.edu.tr
} 


\section{GİRiş}

Süt sığırı işletmelerinde yemleme uygulamaları verimlilik açısından çok önemlidir. İstenilen verim düzeyine ulaşabilmek için diğer faktörlerin iyileştirilmesinin yanı sıra önemli ölçüde rasyonel besleme uygulamalarının da düzenli bir şekilde yapılması gerekmektedir. Kaliteli kaba yem ve karma yem kaynaklarının ve nitelikli çayır-mera alanlarının kullanılması özellikle süt sığırcılığında verimliliğin ön koşullarındandır (Diler ve ark., 2016).

Bölgede doğal ve ekonomik koşullardan dolayı nüfusun temel geçim kaynağını tarım ve hayvancılık oluşturmaktadır. Hayvancılık faaliyeti içerisinde de hem arazinin dağlık ve engebeli olması hem de çayır-mera arazilerinin genişliği meraya dayalı hayvancılığı ön plana çıkarmaktadır. Nitekim Türkiye'de mera arazilerinin \% 37'si Doğu Anadolu Bölgesinde bulunmaktadır (Anonim, 2017a). Çayır ve meralarda bol miktarda bulunan önemli yem bitkileri süt sığırları için ucuz ve zengin protein kaynağı durumundadır. Ancak çayır ve meraların aşırı şekilde otlatılması sonucu doğal yem kaynaklarının verimliliği azalmakta dolayısıyla hem biyolojik çeşitliliğin azalmasina hem de hayvanlarda yetersiz beslenmeye neden olmaktadır (Diler ve ark., 2016)

Süt sığırı işletmelerinde kârlı bir yetiştiricilik için yetiştiricilerin kullanacakları kaba yemleri kendi işletmelerinde üretmeleri esastır. Sı ğırların selülozca zengin kaba yemleri değerlendirme yetenekleri, kaliteli ve ucuz kaba yem sağlayan yem bitkileri kültürünün önemini artırmıştır. Nitelikli yem bitkilerinin kullanımı işletmelerde yoğun yemlerin kullanımını azaltmakta ve ekonomik kazanç sağlamaktadır.

Yonca, silajlık misir, fiğ ve korunga Türkiye'de en fazla yetiştiriciliği yapılan yem bitkileri arasında yer almaktadır (Anonim, 2017b). Erzurum ili ve Narman İlçesi'nde ise çoğunlukla yonca ve korunga yetiştiriciliği yapılmaktadır. Yonca ve korunga yetiştiriciliği bakımından Narman İlçesi'nin Erzurum ilindeki payı sırası ile \% 8.7 ve \% 11'ini oluşturmaktadır (Anonim, 2017b).

$\mathrm{Bu}$ çalışma, Erzurum İli Narman İlçesi'nde sığırcılık işletmelerinde yaygın olarak yapılan hayvan besleme ve yemleme alışkanlıklarının belirlenmesi, bu konuda var olan sorunları ve çözüm önerilerini ortaya koymak amacıyla yürütülmüştür.

\section{MATERYAL VE YÖNTEM}

Araştırma materyalini Erzurum ili Narman İlçesi ve köylerinde bulunan 2033 adet sı̆̆ırcılık işletmesinden tesadüfen seçilmiş 208 sığırcılık işletmesi ile yapılan anketler oluşturmuştur.

Anket çalışmalarında örnek hacminin en az \% 3’ü (Yamane, 2006) veya \% 10'unun (Cochran, 1977) alınmasının yeterli olacağı bildirilmiştir. Narman ilçesinde işletmelerin \% 10.23'ünü oluşturan 208 sığırcılık işletme sahibiyle yüz yüze görüşülerek anket çalışması yapılmıştır.

Elde edilen veriler işletmenin yapısal durumunu etkileyen mevcut hayvan sayıs1 [5 grup ( 1-10, 1120, 21-30, 31-40 ve 41+ BBHB)] dikkate alınarak SPSS (20.0) paket programında analiz edilmiştir. Değişkenler arasındaki ilişkilerin belirlenmesinde kikare bağımsızlık testi uygulanmıştır (Yıldız ve Bircan, 2006).

\section{BULGULAR VE TARTIŞMA}

\section{Yem bitkisi üretimi}

Erzurum İli Narman İlçesi'nde araştırma konusu işletmelerden $\%$ 80.8'inde yem bitkisi ekimi yapıldığ saptanmıştır. Nitekim Demir ve ark. (2013) Kars İli'nde yetiştiricilerin \% 88.7'sinin yem bitkisi ekimi yaptıklarını ifade etmişlerdir. Öte yandan Türkiye'de yapılan diğer çalışmalarda yem bitkisi üretim oranı daha düşük rapor edilmiştir. Yem bitkisi yetiştirme oranını Diler ve ark. (2016) \% 16 (Erzurum), Bakır ve Han (2014) \% 61.2 (Yalova), Han ve Bakır (2009) \% 9 (Ergani) ve Uzal ve Uğurlu (2006) \% 47.22 (Konya) olarak bildirmişlerdir.

Hayvan sayısı ile yem bitkileri yetiştirme oranı arasında anlamlı bir ilişki bulunmuştur $(\mathrm{P}<0.05)$. Hayvan sayısı artışına bağlı olarak yem bitkisi yetiştiren işletmelerin oranında artış görülmüştür (Şekil 1). Hayvan sayısı 1-10 arası olan işletmelerde yem bitkisi yetiştiren işletmelerin oranı en düşük iken hayvan sayısı 21-30 olan işletmelerde bu oran en yüksek değeri almıştır.

Benzer şekilde Diler ve ark. (2016) ve Bakır ve Han (2014) yaptıkları çalışmada hayvan sayısının yem bitkisi yetiştiren işletme sayısını önemli düzeyde etkilediğini saptamışlardır. 


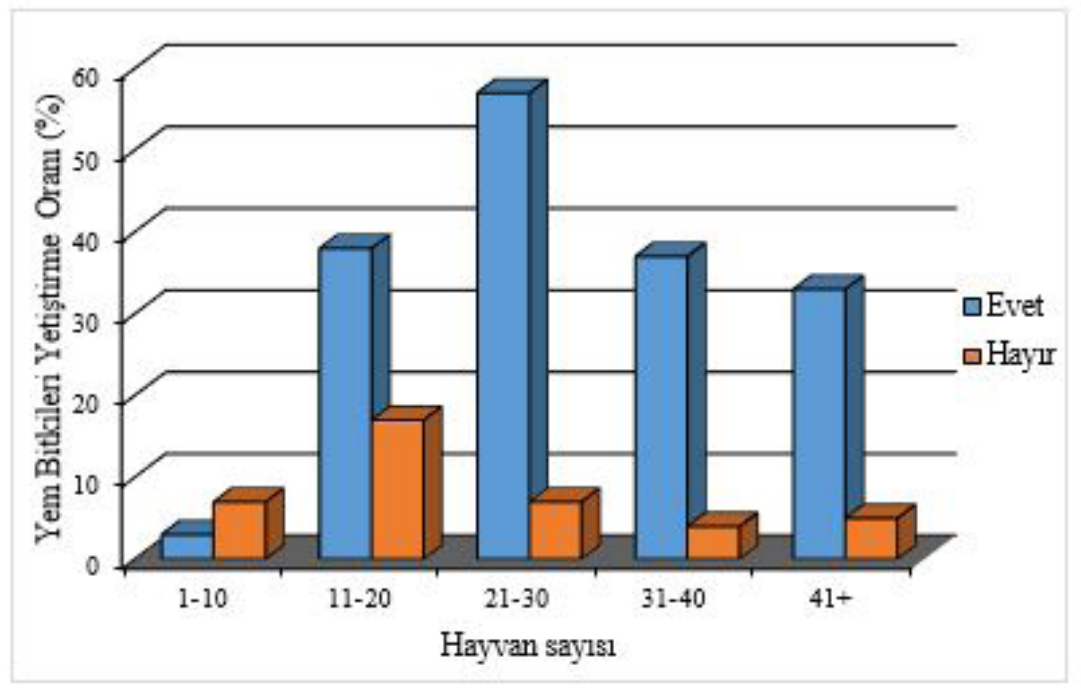

Şekil 1. Yem bitkileri yetiştirme oranlarının hayvan sayısına göre değişimi (\%)

Çalışmada yer alan işletmelerin \% 61.5'inin yonca, \% 60.1'inin arpa, \% 45.7'sinin fiğ, \% 37.5'inin korunga, \% 17.8'inin çavdar, \% 7.7'sinin silajlık mısır ve \% 1.9'unun ise diğer yem bitkilerini yetiştirdikleri tespit edilmiştir. Yapılan diğer çalışmalarda Diler ve ark. (2016) ekimi yapılan yem bitkilerini Erzurum ili Hınıs ilçesinde \% 80 korunga, \% 8 arpa, \% 4 yonca ve $\% 4$ fi $\breve{g}$, Tugay ve Bakır (2008) ise Giresun yöresinde sirasiyla misir (\% 73.2), yonca (\% 20.6), arpa (\% 20.4), fi ̆̆g (\%17.7), korunga (\% 4.6) ve çavdar (\% 2.1) olarak bildirmişlerdir.

İlçede yem bitkileri yetiştiriciliğinin yüksek düzeyde (\% 80.8) olması işletmelerin karlılığ 1 açısından önemlidir.

Ancak süt verimi artışında önemli bir yeri olan silajlık misır (\% 7.7) üretiminin de arttırılması gerekmektedir. Bölgede vejetasyon süresinin kısa olması ikinci ürün mısır üretimini kısıtlamaktadır.

$\mathrm{Bu}$ sebeple silaj üretimi düşüktür. Silajlık mısır üretimini arttırabilmek için yöreye uygun, yüksek verimli ve erkenci çeşitler geliştirilmeli ve tarımı yaygınlaştırılmalıdır.

\section{Mera ve yaylaya çıkma ve yararlanma durumu}

Erzurum bölgesindeki coğrafik koşullar ve mera arazilerinin ekonomik oluşu hayvancılığın meraya dayalı olmasında önemli rol oynamıştır. Narman ilçesinde İşletmelerin \% 96.2'si hayvanlarını meraya çıkarmaktadır (Şekil 2a). Düşük oranda meraya çıkmayan işletmelerde (\%3.8) ise hayvan sayılarının fazla olduğu veya entansif yetiştiricilik yapıldı ̆̆1 görülmüştür.

Benzer şekilde Diler ve ark. (2016) Erzurum ili Hınıs ilçesinde ve Kaygısız ve Tümer (2009) Kahramanmaraş ilinde işletmelerin meraya çıkma oranını \% 99 olarak belirtmişlerdir.

Yapılan diğer çalışmalarda meraya çıkma oranı Kars ilinde \% 87.6 (Demir ve ark. 2013), Giresun yöresinde \% 86.3 (Tugay ve Bakır, 2008) ve Bingöl ilinde ise \% 67.5 (Daş ve ark., 2014) olarak tespit edilmiştir. İşletme sahiplerinin Mart ayında (\% 0.5) hayvanlarını meraya çıkarmaya başladıkları, Mayıs (\% 47.5) ve Haziran (\% 37) aylarında yoğunlaştı görülmüştür. Meradan yararlanma süreleri ise 1 ay $(\% 0.5), 2$ ay (\% 0.5$), 3$ ay (\% 31) ve 4 ay (\% 68) olarak belirlenmiştir. (Şekil 2b). 

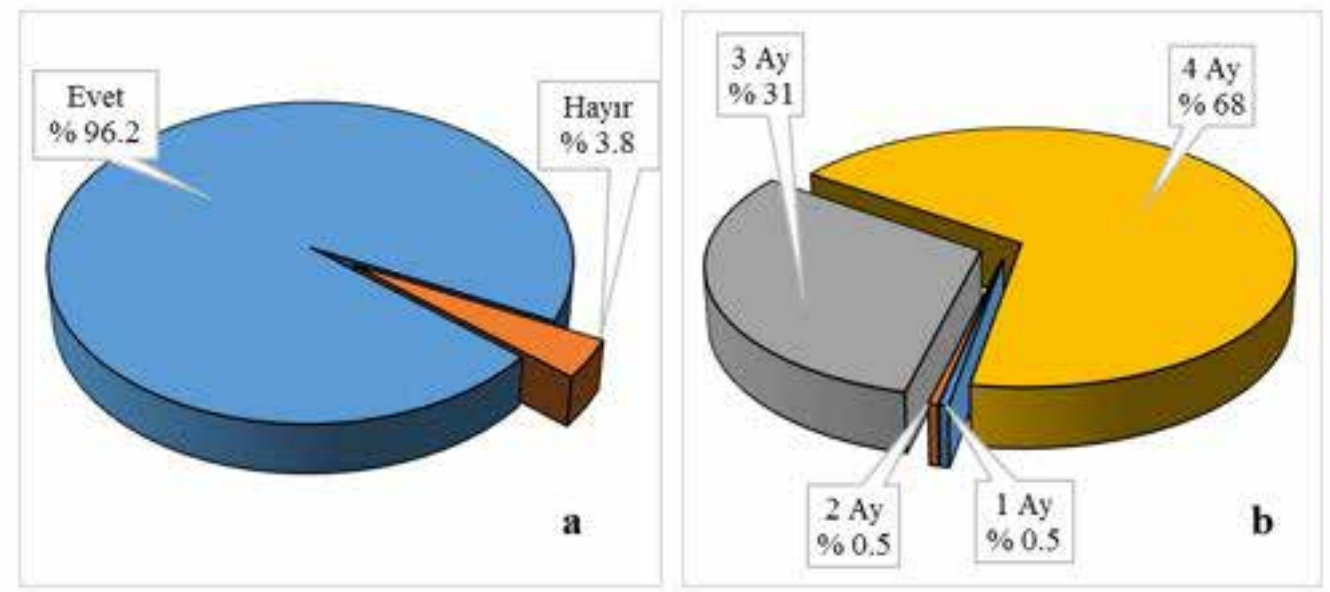

Şekil 2. İşletmelerin meraya çıkma oranı (a) ve otlatma süreleri (b) (\%)

Yapılan diğer çalışmalarda Diler ve ark. (2016) yetiştiricilerin \% 1'inin (Erzurum), Kaygısız ve Tümer (2009) \% 43'ünün (Kahramanmaraş), Han ve Bakır (2009) \% 68.2'sinin (Ergani) Mart ayında, Demir ve ark. (2013) (Kars) ve Tugay ve Bakır (2008) (Giresun) ise Nisan ayında meraya çıkarmaya başladıklarını bildirmişlerdir. Diler ve ark. (2016) meraya çıkışın Mayıs (\% 37) ve Haziran aylarında (\%37), Tugay ve Bakır (2008) ise Mayıs ayında yoğunlaştığını (\% 78.8) bildirmiştir. Merada kalma süresi genellikle 5 ay $(\% 30,3)$ (Tugay ve Bakır,
2008) ve 6 ay (\% 41) (Kaygısız ve Tümer, 2009) olarak ifade edilmiştir. Çalışmalar arasında meraya çıkış ve merada kalma sürelerinde ortaya çıkan farklılıklar bölgelerin mevsimsel özelliklerinden kaynaklanmaktadır.

Erzurum bölgesinde kış mevsiminin uzun olması mera vejetasyonunun geç gelişmesine neden olmaktadır. Ancak işletmecilerin bu durumu dikkate almayarak meranın hazır olmadığ 1 erken dönemde meraya çıkmaya başladıkları görülmektedir.
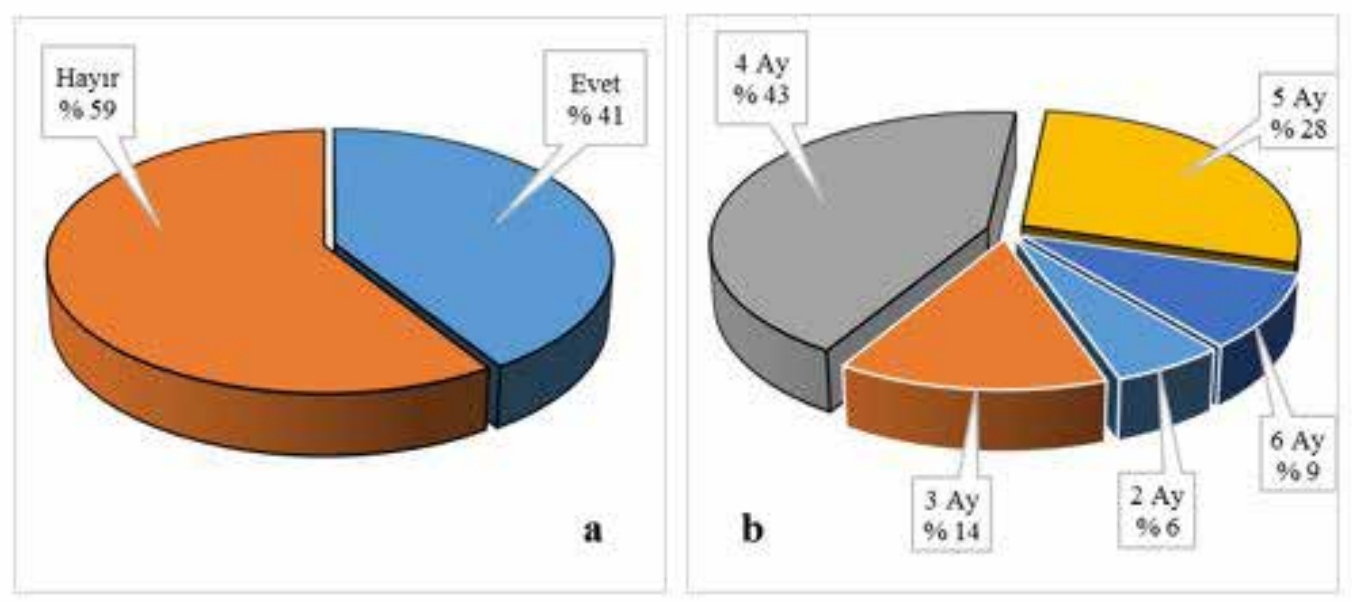

Şekil 3. İşletmelerin yaylaya çıkma (a) ve yaylada kalma (b) süreleri (\%)

Araştırmaya konu olan işletmelerin \% 41'i yaylaya çıkma imkanı olduğunu ifade etmişlerdir (Şekil 3a). Yaylada kalma süresi çoğunlukla $4 \quad-5$ ay (\% $43-$ 28) arasında değişmektedir (Şekil 3b). İşletmecilerin çoğunlukla Mayıs-Haziran aylarında (\%36-35) yaylalara çıktıkları tespit edilmiştir. Yapılan diğer çalışmalarda yaylaya çıkma imkânı ve kalma süreleri sırası ile Erzurum ili Hınıs ilçesinde \% 20 ve 2-3 ay 
(Diler ve ark., 2016), Giresun yöresinde \% 33.2 ve 3-4 ay (Tugay ve Bakır, 2008), Kahramanmaraş ilinde ise \% 8 ve çoğunlukla 3-5 ay (Kaygısız ve Tümer, 2009) olarak bildirilmiştir.

\section{Kaba ve kesif yem temini}

İşletmelerin büyük çoğunluğu kaba yemi kendi üretiyor yetmediği zaman ise dişardan tedarik ediyor (\% 53) iken tamamını kendi işletmelerinden sağlayanlar \% 19, dışarıdan satın alanlar \% 18, kiralık araziden temin edenler ise $\% 10$ olarak belirlenmiştir
(Şekil 4a). Benzer şekilde Demir ve ark. (2013) Kars ilinde, Bogdanović et al. (2012) Sirbistan'da ve Dou et al. (2001) ABD'de işletmelerin kaba yemin büyük oranda kendi üretimleri olduklarını bildirmişlerdir. Bunun aksine Diler ve ark. (2016) Erzurum İli Hınıs İlçe'sinde (\% 63), Daş ve ark. (2014) Bingöl İli’nde (\% 88.7), Kaygısız ve Tümer (2009) ise Kahramanmaraş İlinde (\% 61) işletmelerin büyük bir çoğunluğunun kaba yemi satın aldığını belirtmişlerdir.
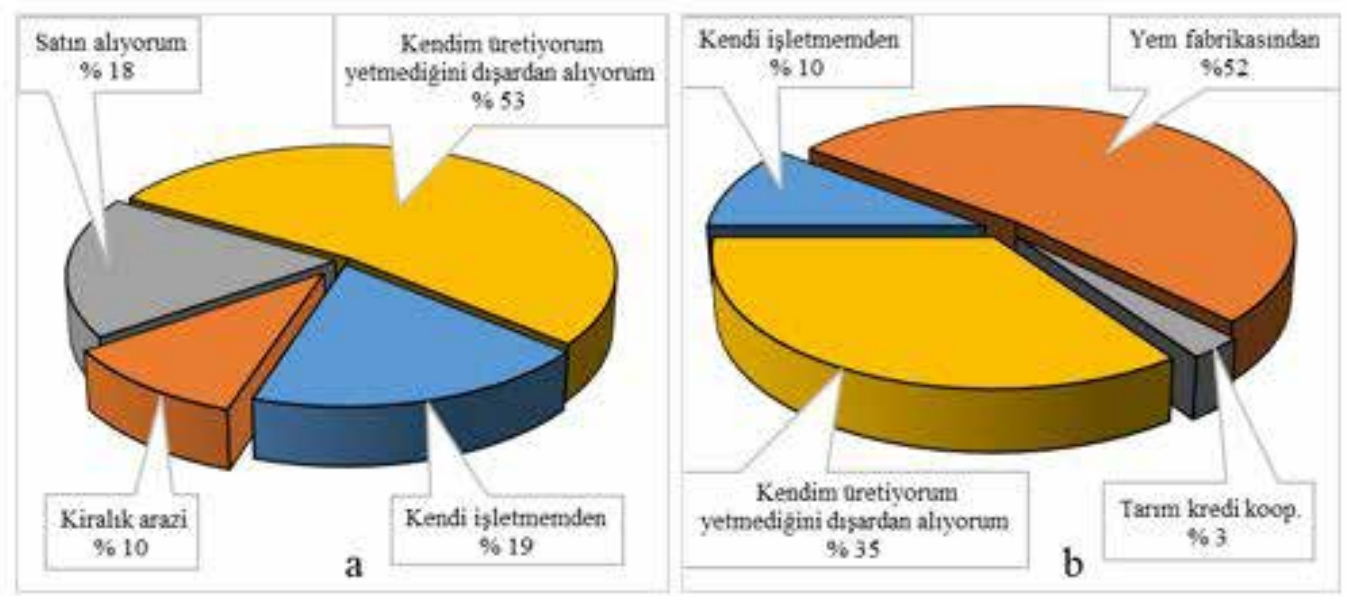

Şekil 4. İşletmelerin Kaba (a) ve kesif (b) yem temin etme kaynakları (\%)

Kaba yem temin kaynaklarını işletmelerdeki hayvan sayısı önemli $(\mathrm{P}<0.05)$ derecede etkilemiştir. İşletmelerdeki hayvan sayısı kaba yem üretimini kendi işletmesinde yapma ve yetmediğinde satın alma oranını arttırmıştır (Şekil 5). Benzer şekilde Diler ve ark. (2016) hayvan sayısının kaba yem temin kaynaklarını önemli $(\mathrm{P}<0.01)$ derecede etkilediğini ifade etmiştir.

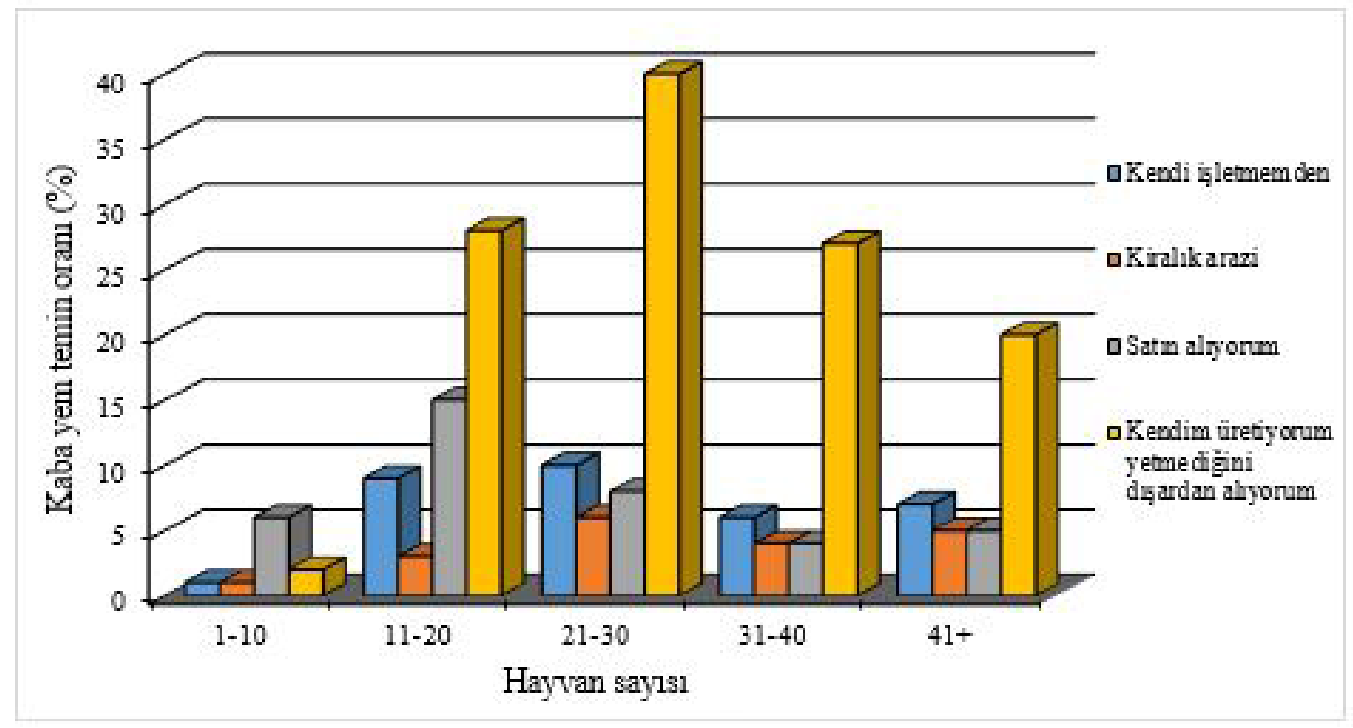

Şekil 5. İşletmelerin hayvan sayısına göre kaba yem temini oranları (\%) 
Kesif yem temini işletmelerde çoğunlukla yem fabrikasından satın alma (\% 52) yolu ile yapılmaktadır. Kendi üretip yetmediğini dişardan satın alanlar \% 35 , Kendi işletmelerinden temin edenler \% 10, Tarım Kredi Kooperatiflerini tercih edenler ise \% 3 olarak belirlenmiş̧ir (Şekil 4b). Diler ve ark. (2016), Daş ve ark. (2014) ve Kaygısız ve Tümer (2009) kesif yemin büyük oranda dışarıdan satın alındığını belirtmişlerdir. Diğer taraftan Dou et al. (2001), Önal ve Özder (2008), Bogdanović et al. (2012) ve Tilki ve ark. (2013) kesif yemin çoğunlukla işletmelerin kendi üretimleri olduğunu ifade etmişlerdir. İşletmelerde yem fabrikalarını tercih edenlerin oranını Tugay ve Bakır (2008) \% 83.4, Diler ve ark. (2016) \% 64 olarak bildirmiştir. Diğer taraftan Soyak ve ark. (2007) \% 65 oranında yem bayilerinin, Demir ve ark. (2013) ise \% 42.5 oranında Tarım Kooperatiflerinin tercih edildiğini ifade etmişlerdir.

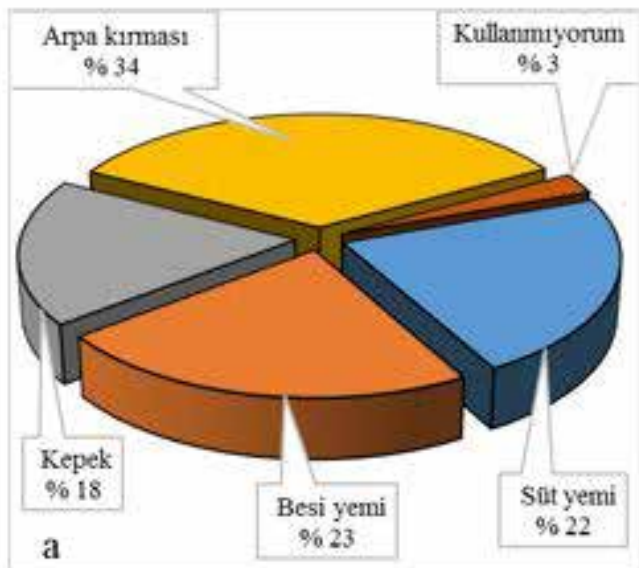

Yetiştiricilerin çoğunlukla satın aldıkları kesif yemden memnun (\% 77.4) oldukları belirlenmiştir. Diler ve ark. (2016) kesif yem memnuniyetini \% 73, Kaygısız ve Tümer (2009) ise \% 48 olarak rapor etmişlerdir.

İşletmeciler satın alınan fabrika yemlerini \% 54.8 oranında kapalı bir depoda muhafaza ederken, $\% 43.3$ oranında dışarıda üstü kapalı, \% 1.9 oranında ise dışarıda üstü açık depolamaktadır. Bunun aksine Bingöl'de Daş ve ark. (2014) \% 88 oranında fabrika yemlerinin ahır dışında depolandığını, Diler ve ark. (2016) ise \% 64 oranında dışarıda üstü kapalı muhafaza edildiğini bildirmişlerdir.

İşletmelerin kesif yem tercih oranları; arpa kırması $\% 34$, besi yemi $\% 23$, süt yemi $\% 22$, kepek $\% 18$ ve kullanmayanların oranı ise \% 3 olarak tespit edilmiştir (Şekil 6a).

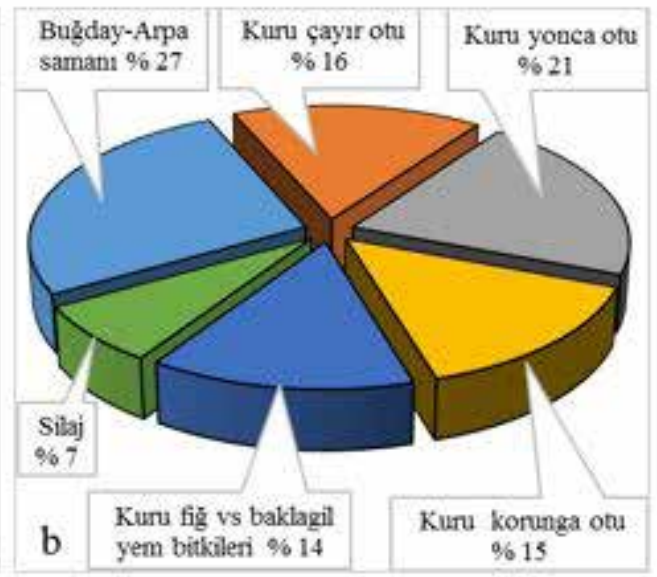

Şekil 6. İşletmelerde kullanılan kesif yem (a) ve kaba yem (b) çeşitlerinin oranları (\%)

Benzer şekilde Diler ve ark. (2016) ve Bakır ve Demirel (2001) işletmelerinde yoğun yem olarak süt yemi, besi yemi, kepek ve arpa kırı̆̆ı kullanıldığını bildirmişlerdir. Ancak Diler ve ark. (2016) Erzurum İli Hınıs ilçesinde arpa kırması (\%6) ve kepek (\%3) kullanımının çok düşük düzeyde olduğunu ifade etmişlerdir.

Narman İlçesi'nde kaba yem olarak ilk sırayı buğday veya arpa samanı (\% 27) almaktadır. Bunu kuru yonca (\% 21), kuru çayır otu (\% 16), kuru korunga (\% 15) ve diğer baklagil yem bitkileri (\% 14) takip etmektedir. Silaj kullanımı ise \% 7 oranında kalmıştır
(Şekil 6b). Türkiye'de yapılan diğer çalışmalar da saman kullanımının yaygın olduğu ve genellikle ilk sırayı aldığı bildirilmiştir (Özyürek ve ark., 2014; Budağ ve Keçeci, 2013; Bakır ve Demirel, 2001). Bunun aksine Bogdanović et al. (2012) Sırbistan'da süt sığırcilığı yapan işletmelerin kaba yem olarak kuru çayır otu, kuru yonca ve mısır silajı kullandıklarını bildirmişlerdir. $\mathrm{Bu}$ araştırmada elde edilen saman kullanım oranı diğer yapılan çalışmalardan daha düşük oranda bulunmuştur.

Kuru çayır otu yetiştiriciliği yapan işletmelerden \% 60'1 kendi üretimleri olan kuru çayır otunu hayvanlarını beslemede kullandıklarını, \% 28'i bir kısmını hayvan 
beslemede kullandığını bir kısmını da sattığını, \% 12'si ise tamamını satıp yerine buğday-arpa samanı aldığını belirtmiştir. Benzer şekilde Diler ve ark. (2016) Erzurum İli Hınıs ilçesinde kuru çayır otunu kendi işletmesinde kullananların oranını $\% 66$, ihtiyacı kadarını işletmesinde kullandı ğı geri kalanını satanların oranını \% 21, kuru çayır otunu satıp dışarıdan saman alanların oranını ise \%13 olarak tespit etmişlerdir.

Sulu kaba yem kaynağı olan ve süt sığırı yetiştiriciliğinde önemli bir yeri olan mısır silajı ilçede $\% 7$ oranında kullanılmaktadır (Şekil 6b). Silaj kullanım oranını Diler ve ark. (2016) çok düşük (\% $0,25)$ düzeyde olduğunu bildirirken, Özyürek ve ark. (2014) \% 13, Bakır ve Han (2014) \% 21.4, Özdemir ve Karaman (2008) \% 30, Önal ve Özder (2008) ise \% 96.5 olarak bildirmişlerdir.

\section{Sığır yemleme yöntemleri}

İşletmecilerin hayvanlarını günde bir defa (\% $0.5)$, iki defa (\% 58.2) ve üç defa (\% 41.3) yemleme yaptıkları tespit edilmiştir. Benzer şekilde Kaygısız ve Tümer (2009) 2 ve 3 defa yemleme yapan işletme sayısını sırasıyla \% 50 ve \% 49 olarak bildirmişlerdir. Diler ve ark. (2016) ise Erzurum İli Hınıs ilçesinde günde bir defa yemleme yapan işletmelerin daha fazla (\% 64) olduğunu ifade etmişlerdir. İşletmeler yemleme yöntemi olarak genellikle karışık yem verme yöntemini
(\% 65.9) izlemektedir. Önce kaba sonra kesif yem verme oranı \% 18.3, önce kesif sonra kaba yem verme oranı ise \% 15.9 olarak tespit edilmiştir. Süt verimleri farklı olsa da bütün ineklere aynı yemi veren işletme oranı $\% 64$ olarak saptanmıştır.

Yetiştiriciler yemlemeyi \%55 oranında kendi bilgilerine göre yapmaktadır. Bunu sırasıyla \% 17 oranında Veteriner hekim, \% 10 oranında yem fabrikaları, \% 10 oranında birlik ve kooperatifler ve $\% 8$ oranında da Ziraat Mühendislerinin tavsiyeleri (Zooteknist), doğrultusunda yemleme yaptıklarını belirtmişlerdir.

\section{Buzağı beslemesi}

Araştırma konusu işletmelerin buzağılara kaba yem olarak \% 29.5 oranında kuru ot, $\% 47.3$ oranında saman, \% 23.2 oranında ise hem kuru ot hem de saman verildiğgi tespit edilmiştir. Buza $\breve{g}_{1}$ beslemede kesif yem kullanımının ise \% 88.8 oranında olduğu tespit edilmiştir. Buzağılarda kullanılan kesif yem çeşitleri Şekil 7'de verilmiştir. Buzağılara başlatma yeminin \% 24, büyütme yeminin $\% 23$, arpa kırmasının ise \% 21 oranında verildiği görülmektedir. Çalışmadaki bulguların aksine Tugay ve Bakır (2008) işletmelerin \% 98.9'unun, Diler ve ark. (2016) ise \% 60'ının buzağılara kesif yem vermediklerini ifade etmişlerdir.

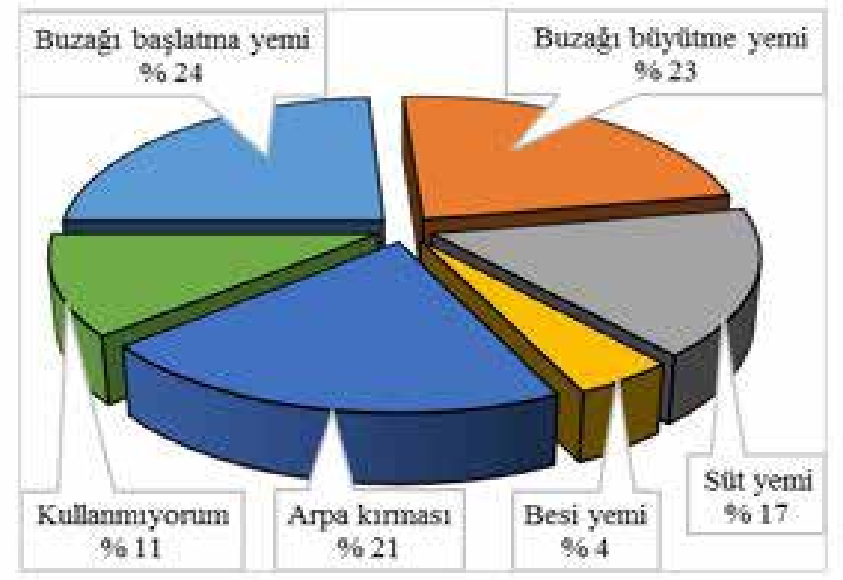

Şekil 7. Buzağılara verilen kesif yem çeşitleri (\%)

Narman'da buzağılara işletmecilerin \% 32'si 1. haftada, \% 36's1 2. haftada, \% 21'i 3. haftada, \% 11 'i ise 3 . haftadan sonra kaba ve kesif yem vermeye başladıkları belirlenmiştir. İşletmecilerin \% 48.1'i 1-3 günlük, \% 44.7'si 4-7 günlük, \% 7.2'si ise bir haftadan sonra buzağılara su vermeye başladıkları tespit edilmiştir. Diler ve ark. (2016) yetiştiricilerin genellikle 4. haftada (\% 52) veya 4 . haftadan sonra (\% 30) kaba ve kesif yem, 1-2 haftalıken (\% 77) ise su vermeye başladıklarını bildirmişlerdir. 
Yurt dişında yapılan çalışmalarda Vasseur ve ark. (2009) ortalama 7 günlük yaşta kesif yem; 3 günlük yaşta kuru ot ve 2.5 günlük yaşta temiz su, Heinrichs ve ark. (1987) ise 1. haftada kesif yem (\% 97.9), 2. haftada kaba yem (\% 78.7) ve su (\% 75.1) verildiğini ifade etmişlerdir.

Erken dönemde buzağılara verilen iyi kaliteli kaba yem rumen gelişimini desteklemekte ve ağırlık artışının daha ekonomik olmasını sağlamaktadır. Genellikle buzağılara 1-2 haftalık yaşta kaba yem, yaklaşık 10. günden sonra kesif yem (buzağı başlatma yemi) verilmelidir. Su ihtiyaçlarını sıvı yemlerle karşılayabilseler de yine de 1 . veya 2 . haftadan itibaren devamlı temiz su verilmelidir. Yetiştiricilerin buzăğ beslemede saman kullanımı dışında diğer kriterlere uydukları görülmektedir.

\section{SONUÇ}

Genel olarak Türkiye'de ve Erzurum ilinde meraya dayalı hayvancılık yapılmaktadır. Narman ilçesinde de işletmecilerin \% 96.2 oranında merayı kullanması, mevcut meraların erken ve yoğun bir şekilde otlatılması, biyolojik çeşitliliğin ve verimliliğin azalmasına dolayısıyla doğal yem kaynaklarının yok olmasına neden olmaktadır. Mera amenajmanı otlatma vejetasyonu, toprak ve diğer doğal kaynaklara zarar vermeden en fazla hayvansal ürünü üretebilecek şekilde planlanmalıdır. Yetiştiricilerin meralarda otlatma

\section{KAYNAKLAR}

Anonim 2017a. T.C. Gıda Tarım ve Hayvancılık Bakanlığı http:// www.tarim.gov.tr/Konular/Bitkisel-Uretim/Cayir-Merave-Yem-Bitkileri Erişim tarihi: 21.03.2017.

Anonim 2017b. Bitkisel ve Hayvansal Üretim İstatistikleri. http:// tuik.gov.tr/ [Erişim tarihi:21.03.2017]

Bakır G, Demirel M, 2001. Van İli ve İlçelerindeki sı̆̆ırcılık işletmelerinde kullanılan yem çeşitleri ve hayvan besleme alışkanlıkları. Tarım Bilimleri Dergisi, 11(1):29-37

Bakır G,Han F, 2014. Yalova ilindeki işletmelerin yapısal özelliklerini etkileyen faktörler: Yem ve besleme alışkanlıkları. Türkiye Tarımsal Araştırmalar Dergisi 1:55-62.

Bogdanović V, Đedović R, Perišić P, Stanojević D, Petrović MD, Trivunović S, Kučević D, Petrović MM, 2012. An assesment of dairy farm structure and characteristics of dairy production sytems in Serbia. Biotechnology in Animal Husbandry. 28 (4): 689-696 mevsimi, otlatma kapasitesi ve münavebeli otlatma gibi unsurlara dikkat etmeleri gerekmektedir. İlçede diğer illerde yapılan bir çok çalışmadan daha yüksek oranda (\% 80.8) yem bitkisi ekimi yapıldığı belirlenmiştir. Ancak dünyada mükemmel bir silaj bitkisi olarak kabul edilen misır üretimi düşük düzeyde (\% 7.7) kalmıştır. Bununla birlikte mısır silajı da işletmelerde \% 7 oranında kullanılmaktadır. Süt sı̆̆ırlarından yüksek verim alınabilmesi ancak iyi bakım ve besleme koşullarında sağlanabilir. Bu koşullarda süt verimi artışında kaliteli silaj önemli bir rol oynamaktadır. Süt sı ğırı işletmelerinde yapılan yemleme uygulamalarında mutlaka silaja yer verilmelidir.

Yetiştiricilerin yarıdan fazlası (\% 55) yemlemeyi kendi bilgilerine göre yapmakta ve bunun sonucu olarak hayvanlarda yetersiz beslenme ve verim düşüklüğü görülmektedir. İşletmeciler yemleme ve besleme konularında ilgili yerlerden gerekli teknik bilgi desteği almalı, gerekli ise meraya ek yemleme yapmalı ve hayvanların ihtiyaçlarına göre dengeli rasyonlar hazırlamalıdır.

Sonuç olarak Erzurum İli'nde bulunan mera ve yaylalar etkin biçimde kullanılmalı ve gerekli ıslah çalışmaları yapılmalıdır. Yem bitkileri ve özellikle silajlık mısır üretimi için yetiştiriciler bilinçlendirilmeli, gerekli teşvik ve destekler arttırmalıdır. İşletmecilerin bilgi, beceri ve eğitim düzeylerinin arttırılması için gereken bilgilendirme çalışmaları ve projeler geliştirilmeli aynı zamanda tarımsal yayım faaliyetleri kırsal alanlarda artırılmalıdır.

Budağ C, Keçeci Ş, 2013. Van'da büyükbaş hayvan besilerinde kullanılan yemler ve besi şekillerine ilişkin bir anket çalışması. Yüzüncü Yıl Üniversitesi Fen Bil. Ens. Derg. 18 (1-2):48-61

Cochran WG, 1977. Sampling Techniques. 3rd Edition. John Wiley\&Sons. New York, USA. 448 p.

Daş A, İnci H, Karakaya E, Şengül AY, 2014. Bingöl İli Damızlık Sı ̆̆ır Yetiştiricileri Birliğine bağlı sı̆̆ırcılık işletmelerinin mevcut durumu. Türk Tarım ve Doğa Bil. Derg. 1(3): 421429

Demir P, Aksu Elmalı D, Işık S, Tazegül R, Ayvazoğlu C, 2013. Kars İli Süt sığırcılık işletmelerinde yem kullanımı ve hayvan besleme alışkanlıklarının ekonomik önemi. Atatürk Üniv. Vet. Bil. Derg. 8(3): 229-236

Diler A, Koçyiğit R, Yanar M, Aydin R, Güler O, Avcı M, 2016. Erzurum ili Hınıs ilçesi sığırcılık işletmelerinde sı ̆̆ır besleme uygulamaları üzerine bir araştırma. Anadolu Tarım Bilimleri Dergisi, 31(1): 149. 
Dou Z, Galligan DT, Ramberg JCF , Meadows C, Ferguson J D, 2001. A Survey of dairy farming in Pennsylvania: Nutrient Management Practices and Implications. J Dairy Sci. 84(4): 966-973.

Han Y, Bakır G, 2009. Ergani İlçesindeki özel besi işletmelerinde besi uygulamaları ve ırk tercihleri. 6. Zootekni Bilim Kongresi 24-26 Haziran, Erzurum.

Heinrichs AJ, Kiernan NE, Graves RE, Hutchinson LJ, 1987. Survey of calf and heifer management practices in Pennsylvania Dairy Herds. J Dairy Sci 70(4): 896-904.

Kaygısız A, Tümer R, 2009. Kahramanmaraş İli süt sığırcılığı işletmelerinin yapısal özellikleri: 3. Hayvan besleme alışkanlıkları. KSÜ Doğa Bil. Dergisi, 12(1): 48-52.

Önal AR, Özder M, 2008. Edirne ili damızlık sığır yetiştiricileri birliğine üye işletmelerin yapısal özellikleri. Namık Kemal Üniversitesi Tekirdağ Ziraat Fakültesi Dergisi, 4(2): 197203.

Özdemir YÖ, Karaman S, 2008. Tokat Merkez İlçedeki süt sığırı ahırlarının yapısal ve çevre koşulları yönünden yeterliliklerinin ve geliştirme olanaklarının araştırılması. Tarım Bilimleri Araştırma Dergisi, 1(2): 27-36.

Özyürek S, Koçyiğit R, Tüzemen N, 2014. Erzincan İlinde süt sığırcılığı yapan işletmelerin yapısal özellikleri: Çayırlı İlçesi örneği. Tekirdağ Ziraat Fakültesi Dergisi, 11(2): 1926.
Soyak A, Soysal Mİ, Gürkan EK, 2007. Tekirdağ İli Süt sığırcılığı işletmelerinin yapısal özellikleri ve bu işletmelerin siyah alaca süt sığırı popülasyonunun çeşitli morfolojik özellikleri üzerine bir araştırma. Tekirdağ Ziraat Fakültesi Dergisi, 4(3): 297-305.

Tilki M, Aydın E, Sarı M, Aksoy AR, Önk, K, 2013. Kars İli sı̆̆ır işletmelerinde barınakların mevcut durumu ve yetiştirici talepleri: 1. Mevcut durum. Kafkas üniversitesi Veteriner Fakültesi Dergisi, 19(1): 109-116, 2013.

Tugay A, Bakır G, 2008. Giresun yöresindeki sığırcılık işletmelerinde kullanılan yem çeşitleri ve hayvan besleme alışkanlıkları. Atatürk Üniv. Ziraat Fak. Dergisi, 39(2): 231-239.

Uzal S, Uğurlu N, 2006. Konya ili besi sığırı işletmelerinin yapısal analizi. Selçuk Üniversitesi Ziraat Fakültesi Dergisi, 20(40): 131-139.

Vasseur E, Borderas F, Cue RI, Lefebvre D, Pellerin D, Rushen J, Wade KM, Passillé AM, 2010. A survey of dairy calf management practices in Canada that affect animal welfare. Journal of Dairy Science. 93(3): 1307-1315.

Yamane T, 2006. Temel Örnekleme Yöntemleri. Çev. Esin A, Bakır MA, Aydın C, Güzbüzsel E, Literatür Yayınları: 53, İstanbul, TÜRKIYY. $528 \mathrm{~s}$.

Yıldız N, Bircan H, 2006. Uygulamalı İstatistik. Nobel Yayın Dağıtım, Ankara, TÜRKIYYE. $402 \mathrm{~s}$. 